\title{
SOME ASPECTS OF RESEARCH AND FARMER USE OF LEGUME-BASED PASTURES IN BRITAIN
}

\author{
R. J. M. HAY* \\ Grasslands Division, DSIR, Gore.
}

\begin{abstract}
Energy considerations, together with the removal of the U.K. Government's subsidy on nitrogen fertilizer, have not shifted farmer emphasis from heavy reliance on bag nitrogen. ADAS officials are still convinced that bag nitrogen rather than legume nitrogen is the answer to increased production, even though U.K. farmers are now applying nitrogen at 20 times their pre-war rates for a mere doubling of stock numbers over this period.

Examples are given of farmers from different regions in Britain who are successfully basing their enterprises on legumes rather than fertilizer nitrogen, Problems of herbage legume seed multiplication are discussed, along with the prejudice legumes suffer in terms of unpredictability, persistence, disease susceptibility, bloat and oestrogenicity.

There is clear need for a large research effort to be mounted in terms of biological nitrogen fixation in the U.K. The relevance to New Zealand agriculture-of a projected move of U.K. farmers away from fertilizer nitrogen is discussed in the light of the proposed Kapuni urea factory.
\end{abstract}

\section{INTRODUCTION}

REM OVAL, of the U.K. Government's subsidy on nitrogen fertilizer in 1972 and oil price rises since 1973-4 have not shifted British farmers' heavy reliance on bag nitrogen for pasture growth. The Common Market standardized milk price paid to producers more than compensated for the extra cost of nitrogen inputs. Thus the strategy of using nitrogen fertilizer as the chief technical input to tap the potential of grassland production was able to continue without serious consideration of alternative farming systems. In 1976, U.K. farmers applied about a million tonnes of nitrogen fertilizer at a cost of about $£ 160$ million.

Leach (1978) and Harvey (1979a) have recently pointed out that this strategy has not been particularly successful. U.K. farmers now apply nitrogen fertilizers at 20 times pre-war rates,

*Recently returned from 16 months' study leave at the Welsh Plant Breeding Station, Aberystwyth. 


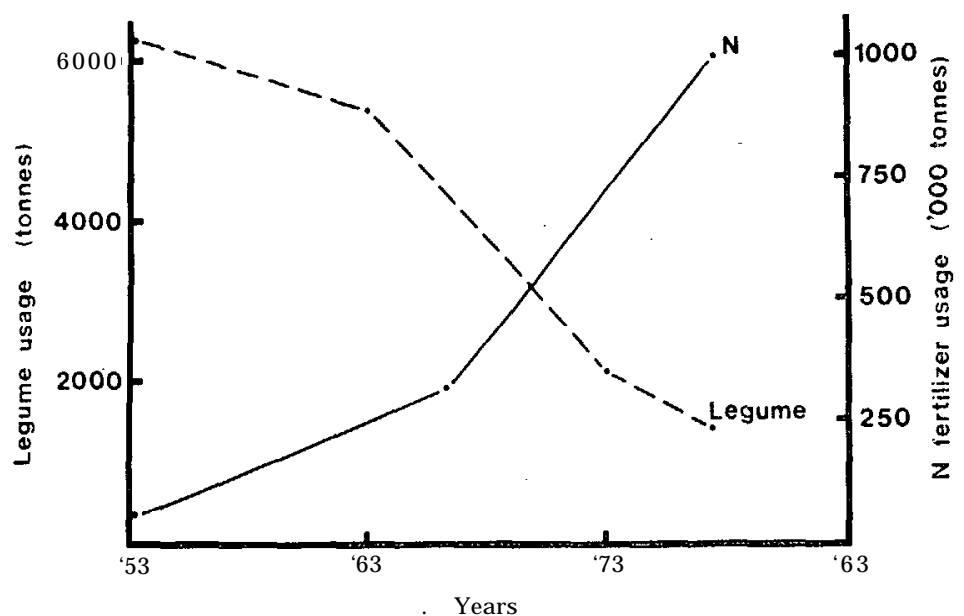

FIG. 1: Legume and nitrogen fertilizer use in the Unifed Kingdom. (Source: U.K. Ministry of Agriculture)

but in 40 years the number of cattle and sheep carried by each hectare of grassland has scarcely doubled. This increase in stocking rate cannot be attributed to nitrogen fertilizer alone. A substantial rise in inputs of feed grains, lime, phosphate and potassic fertilizers (30-fold increase), as well as improved grazing management, can account for much of the improvement in the stockcarrying capacity. It seems that nitrogen allows farmers to programme their operations more easily but does not necessarily raise livestock output per unit area of farm land.

It is more difficult to grow legumes in Britain than in New Zealand, as the temperature optima for their maximum growth $\left(24^{\circ} \mathrm{C}\right.$ for white clover: Mitchell, 1956)are probably not attained as regularly as in New Zealand. In addition, white clover is sometimes subject to cold stress in winter (Harris et al., in press).

\section{ENERGY CONSIDERATIONS}

In 1976 , fertilizers represented $20 \%$ of the energy input into U.K. dairy farms and $24 \%$ of that used on beef farms. Of this, nitrogen accounted for $77 \%$. Although farming in general accounts for only $4 \%$ of the U.K. primary fuel use, it is unlikely to escape the full effects of the energy crisis. U.K. farmers have been insulated from the oil crisis by favourable agreements among nitrogen fertilizer manufacturers and gas suppliers, but these agreements expire in 2 years' time. 


\section{FARMER USE}

In the period 1961 to 1978 , total legume seed sown in the U.K. has declined from 5639 to 1575 tonnes (U.K. Ministry of Agriculture data). The energy crisis from 1974 onward has not halted the decline of legume use, and paradoxically a greater drop in 1978 may be caused by energy/cost considerations of ploughing and reseeding.

The superior feeding value of legumes compared with grasses was reported in the 1933 Welsh Plant Breeding Station report. Although subsequent experiments have confirmed this finding, it has largely been ignored by the agricultural community. Agronomists and advisers have tended to concentrate on how much nitrogen white clover fixes in a sward (Herriott and Wells, 1960; Cowling, 196 1; Widdowson et al., 1963; Whitehead, 1970; Wolton and Brockman, 1970; Chestnutt, 1970, 1972; Reid,1972), regarding clover solely as a nitrogen supplier.

Against this trend have been Ellis Davies, legume breeder at the Welsh Plant Breeding Station (WPBS), and Dr David Thompson, nutritionist of the Grasslands Research Institute (GRI). It was heartening to see lively farmer interest in legumes at conferences I attended. Interestingly, many of their questions on establishment and grazing management could not be answered because of the lack of research in these areas. Recently the Hannah Institute Annual Report (1978), describing the first year of a trial comparing dairy herds grazing ryegrass/Blanca white clover and ryegrass plus $150 \mathrm{~kg} \mathrm{~N} / \mathrm{ha}$, reported no difference in milk yield between the two swards. This is in agreement with findings of a similar trial in Ireland (T. Gately, pers. comm.).

Harvey (1979b) describes three highly productive farming operations to demonstrate that successful farming in the U.K. can be based primarily on grass/legume associations. First a Cotswold farmer, Mr Pat Murray, feeds his cows a year-round forage ration containing $50 \%$ red clover. His 225 -cow herd yields an average of 4500 litres of milk a year, on just 0.75 tonnes of rolled barley concentrates. In September and October the performance of his cows on tetraploid red clover leys was better than on anything else on the farm. He found that Italian ryegrasses were too aggressive for red clover, and that late-flowering ryegrasses such as S23 became dominated. He chose S37 cocksfoot. The higher feeding value of red clover compensated for the lower quality of cocksfoot. There has been no evidence of red clover oestrogens causing fertility problems in his-cows. A bloat preventative is added 
to the drinking water when red clover leys are grazed. Conservation is carried out with a mower-conditioner and includes barn drying with a preservative. A typical sample of hay comprises $75 \%$ tetraploid red clover and $25 \%$ grass. Its D-value is 70 , and crude protein $11.8 \%$

In Hampshire, Mr John Parker farms 1620 ha, 535 ha of which is in cereals. The balance of leys support 1000 dairy cows in eight herds, 1000 ewes, and 200 beef cattle. Tetraploid red clover and lucerne provide late-season grazing for fattening lambs, but their chief role is in silage production. He finds that second and third cuts of the legumes ensile better than those of grass. Legume silages are mixed with the lower quality, high knergy grass and maize silages at feeding. His 4-year grazing leys always include 'Grasslands Huia'.

Mr Ian Howie has produced meat from legumes for many years in Hereford. In winter, fattening steers gain more than $0.9 \mathrm{~kg} /$ day on silages containing at least $30 \%$ red clover. He notes, however, that livestock production from legumes is a hit-and-miss affair, with virtually no research being caried out on ways of integrating legumes into farming systems.

Purdey (1978) reported that Mr Tom McGreath, of Wigtownshire, south-west Scotland, relies on red and white clover as the basis for all his pastures for his 287 dairy cows. Ten years ago he switched to clovers and cut his nitrogen fertilizer application rate from 275 to $100 \mathrm{~kg} \mathrm{~N} / \mathrm{ha} / \mathrm{yr}$. McGreath finds that milk yield of his spring-calving cows drops suddenly when they are moved from high-clover to low-clover pasture. He has lost only one cow from bloat in i-he last 10 years and believes that management, principally strip grazing, can eliminate high risks; Turoa and the Swedish variety Merkur are preferred to S123, which, although persistent, is not sufficiently aggressive in late summer. McGreath uses Huia white clover. He states that one of the biggest attributes of the clovers is that they hold their D-value much longer than grasses. He has averaged over 4550 litres of milk/cow/yr on less than 0.76 tonnes of concentrates, and because of this, plus the low input of fertilizer nitrogen, he achieves a higher gross margin for his enterprise than all-grass farmers with a higher milk yield.

These examples demonstrate that legumes can form a profitable basis for various farming systems in several areas of the U.K.

$$
\text { ADVISORY POLICY }
$$

The policy of heavy nitrogen applications to pasture has been pursued vigorously by ADAS. However, results of a recent study 
by ADAS and the GRI show that stock density on pastures is influenced largely by the amount of compound feeds bought in by the farmer rather than by increased $\mathrm{N}$ use. On dairy farms, nitrogen rate has a small effect on animal output, but on beef and sheep farms it has none (Kilkenny, 1978).

The main criticisms of legumes by advisers and agronomists are their unpredictability, poor persistence, disease susceptibility, poor availability of seed and the metabolic disorders such as bloat and phyto-oestrogen activity they can cause.

\section{(a) UNPREDICTABILITY}

This criticism has come from observations of mixed swards managed solely for the grass component. However, the seasonal distribution of grass/clover swards in the U.K. indicates that clover growth is impressively predictable in mid to late summer (J. Morrison-, pers. comm.). In fact, DM production from grass/clover pastures appear to fit animal feed demands better than does grass plus nitrogen swards (Chestnutt and Lowe, 1970; Morrison, 1978).

\section{(b) Persistence}

This is linked to disease as well as management, especially when considering pure swards of red clover and lucerne. White clover, sown in pasture mixtures, generally receives heavy dressings of nitrogen fertilizer from establishment onwards, and, with a silage cut taken at least once a year, it is unlikely that the plant can contribute greatly to total production. Nitrogen-tolerant white clover varieties (Evans and Davies, 1977) have improved this situation a little, but these varieties have limitations in other areas. White clover persists well under sheep grazing in the Welsh and Scottish hills (Aldrich, 1978).

\section{(c) DISEASE}

In arable areas, clover rot (Scferofinia trifoliorum) is perhaps the most important of the legume diseases in the U.K. European varieties of red and white clover have shown resistance to this disease, and this year a medium-large leaved breeding line of white clover AC32 from WPBS showed very good resistance to Sclerotinia at several sites (W. Ellis Davies, pers. comm.). Generally, European varieties of red and white clover are susceptible to eelworm (Ditylenchus diesaci), but resistance to eelworm has been discovered in local British varieties of red clover (Davies, 1975). 
Breeding for resistance to eelworm is at an advanced stage both at the Plant Breeding Institute, Cambridge, and at WPBS. Varieties of lucerne resistant to Verticillium wilt (V. albo-atrum) and to bacterial wilt (Corynebacterium insidiosum) are available.

\section{(d) Availability of Seed}

In 1977 the U.K. produced only $2 \%$ of the white clover seed used, with New Zealand supplying $70 \%$ of requirements. This prevents better-adapted U.K. varieties from being used. This year the situation has been eased by an agreement with Denmark to investigate seed production of WPBS white clover varieties with a view to multiplying the high seed producers. This may have consequences on sales of Huia in Britain.

Tetraploid red clover varieties have seed yields in the U.K. and Europe barely reaching $200 \mathrm{~kg} / \mathrm{ha}$. Unless seed production is dramatically raised, some researchers fear that tetraploid varieties will be dropped altogether from agricultural use. This may favour sales of Pawera to Europe as it has done well in National List trials and, if recommended, may be one of the few tetraploid varieties of which seed is readily available.

\section{(e) BLOAT}

Bloat can be readily prevented by established management and chemical methods. Plant breeders have made little progress in combating this problem because of the difficulty in manipulating plant chemical composition. Two approaches are a reduction in soluble proteins which is being investigated in Canada (K. Clark, pers. comm.), and resistance to enzyme attack by proteins which may prevent sudden release of soluble proteins (D. 'Wilson, pers. comm.). However, care will have to be exercised, as these protein factors being selected against may be closely related to factors causing superior growth rates of animals fed legumes (G. Moseley, pers. comm.). A third approach, selection for an increase in tannins, is difficult to achieve because the important herbage legumes used in Britain and New Zealand are extremely low in tannins (Davies, 1975) .

\section{Phyto-OESTROGENS}

Lucerne and red clover when grazed at mating can produce infertility in sheep (Lightfoot, 1974; Thomson, 1975). No evidence has been produced either from research or from the farming community to show that thefertility of cattle is adversely affected by these legumes. 
The Australians have produced two varieties of red clover low in phyto-oestrogens, and a programme at WPBS is producing low formonoetin populations (Gosden et al., 1978).

However, concern has been expressed that by reducing the oestrogenicity, positive effects such as increased milk production in lactating sheep (oestrogenic), and increased growth rate in steers (anabolic), may be lost.

\section{RESEARCH}

The 1977 report of the Joint Consultative Organization for Research and Development in Agriculture and Food (JCO) endorses the Grassland and Forage Committee's view by stating, ". . . we are convinced that there is an increasingly important role for legumes, but especially white clover in lowland, upland and hill farming systems, and this justifies increased effort".

However, I saw little evidence of applied legume research at U.K. agricultural research stations. Any extra money made available for legume research seems to have been channelled into quite basic research. There has been no attempt to look at management X season interactions with grazed white clover-based pastures, investigating frequency, intensity and duration of. grazing, since the work of Martin Jones (1933) . There has been little work done to define the management best suited to each of the eight U.K.-bred white clover varieties. Environmental effects under grazing have not been investigated adequately. All this work is essential to farmers who want to use legume-based swards on their farm.

A serious deficiency in U.K. nitrogen research is the lack of study of nitrogen cycling in the field under grazing - a line of research that should have received high priority following a 1975 estimation that only one-half of the nitrogen applied was taken up by plants.

The preoccupation with breeding for large-leaved white clovers in the U.K. and Europe has not been wholely justified as these cultivars tend to be less persistent under grazing (D. R. Evans, pers. comm.), and although the harvest index has been increased, the total above-ground yield was shown by Rhodes and Harris (1978) to have remained the same.

The incorporation of Mediterranean cool-season growth characteristics- into white clover has not been particularly successful as it 'is often associated with a lack of winter hardiness (Davies, 1964) . 
It is surprising that more work is not being done with Lotus pedunculatus in the U.K., as both 'Grasslands Maku' and 'G4703' were amongst the few legume species, including red clover and lucerne, that came through the 1978-9 winter at the WPBS with little cold injury. Charlton (1975) has demonstrated the potential of this material in the hills of West Scotland, but Davies (1969) masked any advantages that lotus may have had over white clover by applying high dressings of $\mathrm{P}, \mathrm{K}$ and lime. I think lotus could have an important'role to play on low-pH, low-phosphate peaty soils in Wales and Scotland where researchers are finding white clover establishment difficult (Munro et al., 1973; Newbould, 1974).

\section{CONCLUSION}

Energy price trends are likely to make liberal nitrogen use less profitable. If the EEC pricing structure for agricultural products is eased (and this year for the first time prices of dairy products have been pegged at last year's level), a return to low-input farming systems based upon grazed grass/legume associations is possible, with most nitrogen fertilizer use restricted to the most productive cropping soils. To effect this change with a minimum decrease in production, management systems to maximize production from grass/legume swards have to be researched now.

A few farmers are successfully using legumes and very low nitrogen inputs to achieve outputs similar to high nitrogen users, but there appear to be many farmers and advisers in the U.K. who have little idea how to manage grass/clover swards. Thus it is essential that researchers find the answers now to the questions advisers and farmers will be asking in the not too distant future.

With the possibility of a urea plant at Kapuni it is important that New Zealand farming does not make the same mistakes that have been made in the U.K. It will be all too easy for farmers to use extra nitrogen as a substitute for skilful pasture management. New Zealand will then have lost the advantage it has over most other countries in the capacity to meet nitrogen requirements for livestock production by nitrogen fixation alone.

\section{REFERENCES}

Aldrich, D. T. A., 1978. The way ahead with white clover. Proc. NIAB Fellows' Conf., Aberystwyth, pp. 1-2.

Charlton, J. F. L., 1975. J. Br. Grassld Soc., 30: 251-7. 
Chestnutt, D. M. B., 1970. Rec. agric. Res. (Nth Ir.) , 18: 143-54.

1972. J. Br. Grassld Soc., 27: 211-6.

Cowling, D. W., 1961. J. Br. G russld Soc., 16: 281-90

Chestnutt, D. M. B.; Lowe, J., 1970. Occ. Symp. N o. 6, Br. Grassld Soc., 191-213.

Davies, W. Ellis, 1964. The prospects of better clovers. In Seed Trade R eview, J. of the Seed Trade Ass. U.K.

1969. J. Br. Grassld Soc., 24: 264-70.

1975. Plant breeders' objectives for the future. In GRI/ADAS Symp., Red Clover Production and Utilisation: 10-12.

Evans, D. R.; Davies, W. Ellis, 1977. Ann. Rep. W elsh Pt. Breed. Stn, 1976: 23-30.

Gosden, A. F.; Davies, W. Ellis; Jones, Raymond, 1978. Eucarpia Conf. on Forage Legumes, Cracow (in press).

Harvey, G. 1979a: New Scientist: 484-6. 1979b: Fmrs W kly (March 23), 26-9.

Harris, W.; Rhodes, I.; Mee, S. S., J. B r. G rassld A ss. (in press).

Herriott, J. B. D.; Wells, D., 1960. J. B r. Grassld Soc., 15: 63-9.

Jones, Martin, 1933. Emp. J. expl. Agric., I: 43-57.

Kilkenny, J. B., 1978. B r. Soc. Anim. Prod. (Summer Meeting): 29-37.

Leach, G., 1978. Energy and Food Production. I. P. C. Science and Technology Press. $137 \mathrm{pp}$.

Lightfoot, R. J., 1974. Proc. Aust. Soc. Anim. Prod., 10: 113-21.

Mitchell, K. J., 1956. Proc. VIIth Int. Grassld Congr., Palmerston North. $58-63$.

Morrison, J., 1978. Proc. Br. Soc. Anim. Prod. (Summer Meeting) : 7-12.

Munro, J. M. M.; Davies, D. A.; Thomas, T. A., 1973. J. Br. Grassld Soc. 28: $247-55$.

Newbould, P., 1974. J. Br. G rassld Soc., 29: 241-7.

Purdey, I., 1978. Fmrs Wkly (October 6). pp. 102-4.

Reid, D.. 1972. I. agric Sci.. Camb.. 79: 291-301.

Rhodes, 'I.; Harris, W. 1978. Br. Grassld Soc. Occ. Symp. N o. 10: 55-60.

Thomson, D. J., 1975. j'. B r. G rassl d Soc., 30: 149-55.

Whitehead, D. C., 1970. Bull. 48 Commonw . Bur. Past. Fld Crops. Farnham Roy. Commonw. Agric. Bur. 210 pp.

Widdowson, F. V.; Penny, A.; Williams, R. J. B, 1963. Expl. Husb.. 9: 28-34.

Wolton, K. M.; Brockman, J. S., 1970. J. B r. Grassld Soc., 25: 7- 19. 